\title{
Pola Konsumsi dengan Terjadinya Sindrom Metabolik di Indonesia
}

\author{
Consumption Patterns with Occurrence of Metabolic Syndrome in \\ Indonesia
}

\author{
Suhaema*, Herta Masthalina***
}

\author{
*Jurusan Gizi Politeknik Kesehatan Kementerian Kesehatan Mataram, **Jurusan Gizi Politeknik Kesehatan \\ Kementerian Kesehatan Medan
}

\begin{abstract}
Abstrak
Terjadinya sindrom metabolik diduga berhubungan dengan pergeseran gaya hidup masyarakat yang berubah menuju masyarakat modern, dari mengonsumsi makanan tradisional beralih ke makanan instan dan kebaratbaratan. Penelitian ini bertujuan untuk mengetahui prevalensi sindrom metabolik dan determinannya dari pola konsumsi, meliputi konsumsi sayur dan buah serta pola makan makanan manis, asin, berlemak, lauk hewani berpengawet, dan penggunaan penyedap. Penelitian ini merupakan bagian dari analisis lanjut data Riset Kesehatan Dasar tahun 2013 dengan desain potong lintang. Jumlah sampel setelah pembobotan adalah 1.878 .578 orang dengan kriteria berusia 18 tahun ke atas. Pengumpulan data pola konsumsi, antropometri, klinis, dan biomedis telah dilakukan. Analisis data menggunakan kai kuadrat dan regresi logistik biner. Prevalensi sindrom metabolik di Indonesia sebesar $23 \%$, pada perempuan $26,6 \%$ dan pada laki-laki $18,3 \%$. Konsumsi makanan manis lebih dari satu kali per hari sebanyak 43,5\% dan kurang dari satu kali per hari 10,5\% dengan risiko mengalami sindrom metabolik sebesar 6,567 kali. Konsumsi makanan asin yang termasuk dalam kategori sering memiliki proporsi sindrom metabolik sebesar 100\% dengan risiko mengalami sindrom metabolik sebanyak 6,363 kali. Terdapat hubungan yang signifikan (nilai $p<0,05$ ) antara pola konsumsi sayur dan buah, frekuensi konsumsi makanan manis, asin, berlemak, lauk hewani yang diawetkan, penggunaan penyedap, dan mi instan dengan kejadian sindrom metabolik pada usia produktif.

Kata kunci: Pola konsumsi makanan, sindrom metabolik, usia produktif
\end{abstract}

\section{Abstract}

Occurrence of metabolic syndrome is assumedly related to the changing of people's lifestyle into modern society, from consuming traditional food to instant food and be westernized. This study aimed to determine metabolic syndrome prevalence and its determinants from consumption patterns including vegetable and fruit consumption as well as consumption patterns of sweet, salty, fatty food, preserved animal side dishes and use of seaso- nings. This study was a part of advanced Basic Health Research 2013 data analysis by cross sectional design. A total of sample after weighting was $1,878,578$ people on aged 18 years old and older. Collection of consumption pattern, anthropometry, clinic and biomedic data had been conducted. Data analysis used chi square and binary logistic regression. Metabolic syndrome prevalence in Indonesia is $23 \%, 26.6 \%$ on women and $18.3 \%$ on men. Consuming sweet food more than once a day was $43.5 \%$ and less than once a day was $10.5 \%$ with 6.567 times risk of suffering metabolic syndrome. Salty food consumption included into often category had metabolic syndrome proportion worth $100 \%$ with 6.363 times risk of suffering metabolic syndrome. There was a significant relation ( $p$ value $<0.05$ ) between the pattern of vegetable and fruit consumption, frequency of sweet, salty, fatty food, preserved animal side dishes, the seasoning use and instant noodle with metabolic syndrome occurrence in productive age.

Keywords: Food consumption patterns, metabolic syndrome, productive age

\section{Pendahuluan}

Sindrom metabolik didefinisikan sebagai konstelasi yang saling berhubungan dari pelbagai faktor fisiologis, biokimia, klinis, dan metabolik yang secara langsung meningkatkan risiko penyakit kardiovaskular, diabetes melitus tipe 2 dan semua penyebab kematian. ${ }^{1}$ Sekumpulan gejala yang terdapat pada sindrom metabolik, yaitu obesitas sentral, peningkatan kadar trigliserida darah, penurunan kadar high density lipoprotein (HDL) kolesterol darah, tekanan darah tinggi, peningkatan

Korespondensi: Suhaema, Jurusan Gizi Politeknik Kesehatan Kemenkes Mataram, Jl. Prabu Rangkasari Dasan Cermen Sandubaya, No.Telp: 0370633837,e-mail: emma_sbw2@yahoo.com 
kadar glukosa darah dan resistensi insulin.1,2

Saat ini, sindrom metabolik telah menjadi masalah kesehatan masyarakat dan tantangan klinis di seluruh dunia berkaitan dengan urbanisasi, asupan energi yang berlebihan, peningkatan kejadian obesitas dan gaya hidup sedentary serta terkait dengan dampak yang ditimbulkannya. Diperkirakan pada lima hingga sepuluh tahun mendatang akan terjadi peningkatan risiko diabetes melitus tipe 2 sebanyak lima kali lipat dan penyakit kardiovaskular sebanyak dua kali lipat akibat dari penyakit ini. Pasien dengan sindrom metabolik memiliki risiko stroke sebesar dua sampai dengan empat kali dan risiko infark miokard hingga tiga sampai empat kali. ${ }^{3}$

Prevalensi sindrom metabolik sulit diketahui secara pasti karena perbedaan diagnosis yang digunakan. World Health Organization (WHO) tahun 1999 menyatakan bahwa penyakit ini didasari oleh resitensi insulin yang disertai hipertensi (tekanan darah $\geq 140 / 90 \mathrm{mmHg}$ ), hipertrigliseridemia ( $\geq 150 \mathrm{mg} / \mathrm{dL}$ ), rendahnya kadar HDL ( $<35 \mathrm{mg} / \mathrm{dL}$ pada laki-laki dan $<39 \mathrm{mg} / \mathrm{dL}$ pada perempuan), obesitas (rasio lingkar pinggang pinggul $>$ 0,9 pada laki-laki dan $>0,85$ pada perempuan atau indeks massa tubuh (IMT) di atas $30 \mathrm{~kg} / \mathrm{m}^{2} .{ }^{3}$ Berdasarkan kriteria tersebut, dilaporkan jumlah penderita sistem metabolik pada orang dewasa di Amerika mencapai $25 \% .4$

National Cholesterol Educational Program Adult Treatment Program III (NCEP ATP III) tahun 2001 menetapkan kriteria sindrom metabolik adalah bila menemukan tiga dari lima komponen yang terdiri dari tekanan darah $\geq 130 / 85 \mathrm{mmHg}$ atau dalam pengobatan antihipertensi, kadar kolesterol HDL $<40 \mathrm{mg} / \mathrm{dL}$ pada laki-laki dan $<50 \mathrm{mg} / \mathrm{dL}$ pada perempuan, hipertrigliseridemia ( $\geq 150 \mathrm{mg} / \mathrm{dL}$ ), kadar glukosa serum puasa yang tinggi $(>110 \mathrm{mg} / \mathrm{dL}$ ) dan obesitas sentral (lingkar perut laki-laki $>102$ centimeter dan perempuan $>88$ centimeter). ${ }^{1}$ Kriteria penetapan obesitas sentral tersebut berbeda dengan negara Asia Pasifik, yaitu bila lingkar perut $\geq 90$ centimeter dan perempuan $\geq 80$ centimeter. ${ }^{3,5}$

Menggunakan kriteria NCEP ATP III, National Health and Nutrition Examination Survey (NHANES) 2003 - 2006 melaporkan sekitar 34\% orang dewasa di Amerika mengalami sindrom metabolik dengan prevalensi faktor risiko sindrom metabolik yaitu obesitas sentral $53 \%$, hipertensi $40 \%$, dan 39\% mengalami hiperglikemia. ${ }^{6}$ Hasil penelitian Cardiovascular Risk Factor Multiple Evaluation in Latin America (CARMELA), ${ }^{7}$ pada populasi dewasa menyatakan kejadian sindrom metabolik sebesar 27\% di Mexico dan 14\% di Quito. Di Indonesia, dengan menggunakan kriteria NCEP ATP III dengan modifikasi kriteria untuk Asia, dilaporkan bahwa prevalensi sindrom metabolik di Jakarta sebesar 28,4\% yang terdiri dari $25,4 \%$ pada laki-laki dan $30,4 \%$ pada perempuan. Komponen sindrom metabolik terbanyak pa- da laki-laki adalah hipertensi $(84,7 \%)$ diikuti oleh hipertrigliseridemia $(83,4 \%)$, obesitas sentral $(75,5 \%)$, hiperglikemia $(50,9 \%)$ dan kadar HDL yang rendah $(43,6 \%)$. Sedangkan pada perempuan, komponen sindrom metabolik terbanyak adalah obesitas sentral $(91,3 \%)$, diikuti oleh hipertensi $(84,1 \%)$, hipertrigliseridemia $(66,1 \%)$, kadar HDL yang rendah $(57,8 \%)$ serta hiperglikemia $(50,2 \%) .8$ Penelitian lain di Jakarta mendapatkan prevalensi sindrom metabolik pada kelompok eksekutif sebesar $21,6 \%, 24,8 \%$ pada laki-laki dan $11,8 \%$ pada perempuan. ${ }^{9}$

Insiden sindrom metabolik diduga berhubungan dengan pergeseran gaya hidup akibat pengaruh globalisasi. Gaya hidup masyarakat berubah menuju masyarakat modern dengan pola konsumsi makanan tradisional beralih ke makanan instan dan kebarat-baratan. Penelitian kohort yang dilakukan Lutsey, dkk., ${ }^{2}$ selama sembilan tahun dengan melibatkan 9.514 subjek mendapatkan bahwa terdapat sekitar $40 \%$ kasus baru sindrom metabolik. Pada penelitian ini, disimpulkan bahwa makanan barat, konsumsi daging, dan makanan gorengan meningkatkan sindrom metabolik. Sementara itu, penelitian lain mendapatkan konsumsi produk berbahan dasar susu rendah lemak, ikan, dan sereal yang tinggi melindungi terjadinya sindrom metabolik. ${ }^{10}$

Temuan lain yang dilaporkan dari Riset Kesehatan Dasar (Riskesdas) tahun 2013 adalah kecenderungan proporsi penduduk usia $>10$ tahun yang kurang mengonsumsi sayur dan buah sebanyak 93,5\%. Konsumsi makanan atau minuman manis $\geq 1$ kali dalam sehari secara nasional adalah $53,1 \%$, sedangkan konsumsi makanan berlemak, berkolesterol dan makanan gorengan $\geq 1$ kali per hari sebesar $40,7 \%$ dan penduduk Indonesia mengonsumsi penyedap $\geq 1$ kali dalam sehari sebesar 77,3\%.11 Pelbagai penelitian mendapatkan bahwa pola konsumsi tersebut yang cenderung rendah serat namun tinggi lemak, kolesterol, gula dan natrium serta gaya hidup kurang gerak dan tidak aktif ini merupakan faktor risiko yang berkaitan dengan obesitas dan sindrom metabolik serta penyakit degeneratif lainnya. $8,11-13$

Prevalensi sindrom metabolik ini diperkirakan akan terus mengalami peningkatan yang berdampak pada meningkatnya jumlah penderita penyakit kardiovaskular dan kelangsungan hidup seseorang. ${ }^{14,15}$ Penelitian Klien, ${ }^{16}$ menyatakan bahwa $21,7 \%$ pasien gangguan jantung dengan sindrom metabolik mengalami kejadian kardiovaskular dan kematian. Hasil Survei Kesehatan Rumah Tangga tahun 2001 menunjukkan bahwa penyakit kardiovaskular menduduki peringkat pertama penyakit degeneratif penyebab kematian di Indonesia sebesar 49,9\%.17 Temuan tersebut menunjukkan bahwa sindrom metabolik dan faktor risikonya perlu mendapat perhatian serius agar tidak mengarah pada berkembangnya penyakit degeneratif. ${ }^{11}$ Berdasarkan latar be- 
lakang tersebut, penulis ingin melakukan kajian atau analisis lanjut pola konsumsi makanan berhubungan dengan terjadinya sindrom metabolik pada usia produktif.

\section{Metode}

Penelitian ini merupakan bagian dari penelitian analisis lanjut hasil Riskesdas tahun 2013 yang dilakukan pada tahun 2014 dengan kajian analisis model faktor determinan terjadinya sindrom metabolik berdasarkan pola konsumsi dan gaya hidup pada usia produktif. Data yang dianalisis diperoleh dari Laboratorium Manajemen Data, Badan Penelitian dan Pengembangan Kesehatan, Kementerian Kesehatan Republik Indonesia. Jenis penelitian ini adalah analisis kuantitatif dengan menggunakan rancangan yang sama dengan Riskesdas tahun 2013 yaitu potong lintang berskala nasional.

Populasi dalam penelitian ini adalah populasi yang digunakan dalam Riskesdas tahun 2013, dengan populasi target adalah penduduk berusia 18 tahun ke atas yang terlibat dalam Riskesdas serta pengumpulan data pola konsumsi makanan, pengukuran antropometri, pemeriksaan klinis dan biomedis telah dilakukan. Sampel Riskesdas yang memenuhi kriteria berjumlah 46.000 orang. Kriteria sampel adalah penduduk yang berusia 18 tahun ke atas yang menjadi responden pada Riskesdas tahun 2013, telah dilakukan pengumpulan data mengenai pola konsumsi makanan dan aktivitas fisik, telah bersedia dilakukan pengukuran antropometri (lingkar perut), telah dilakukan pemeriksaan klinis (tekanan darah), dan telah dilakukan pemeriksaan biomedis (kolesterol HDL, trigliserida, dan kadar glukosa darah puasa).

Penentuan sampel pada Riskesdas menggunakan desain sampling yang kompleks (pengambilan sampel bertingkat, beberapa metode pengambilan sampel sekaligus). Oleh karena itu, dalam penelitian ini dilakukan penyesuaian dengan pembobotan menggunakan perangkat lunak Statistical Product and Service Solutions (SPSS). Pembobotan dilakukan untuk menyamakan peluang terpilihnya sampel pada setiap strata agar varian dalam sampel sama dengan varian dalam populasi sehingga mendukung generalisasi ke populasi. Apabila pembobotan tidak dilakukan dalam analisis, maka dapat menyebabkan tidak akuratnya estimasi parameter populasi, yaitu menjadi di bawah perkiraan yang berakibat pada confidence interval (CI) kurang tepat dan meningkatkan kesalahan tipe I. ${ }^{18}$ Jumlah sampel yang memenuhi kriteria adalah 31.998 orang dari 35.409 orang sampel yang telah dilakukan pemeriksaan biomedis, antropometri, dan pola makan. Setelah dilakukan pembobotan, maka total sampel yang dianalisis berjumlah 1.878 .578 orang.

Variabel bebas adalah pola konsumsi makanan yang meliputi konsumsi sayur dan buah serta pola makan ter- tentu yang terdiri dari makanan manis, asin, berlemak, hewani berpengawet, dan penyedap. Adapun variabel terikat adalah terjadinya sindrom metabolik mengacu pada kriteria NCEP ATP III dengan modifikasi dari International Diabetes Federation (IDF) tahun 2005, yaitu seseorang yang memiliki sedikitnya tiga dari kriteria di antaranya obesitas sentral (lingkar perut $\geq 80$ centimeter untuk perempuan dan laki-laki $\geq 90$ centimeter), peningkatan kadar trigliserida darah $(\geq 150 \mathrm{mg} / \mathrm{dL}$, atau $\geq 1,69 \mathrm{mmol} / \mathrm{L})$, penurunan kadar kolesterol HDL $(<40$ $\mathrm{mg} / \mathrm{dL}$ atau $<1,03 \mathrm{mmol} / \mathrm{L}$ pada laki-laki dan pada perempuan $<50 \mathrm{mg} / \mathrm{dL}$ atau $<1,29 \mathrm{mmol} / \mathrm{L}$ ), peningkatan tekanan darah (tekanan darah sistolik $\geq 130$ $\mathrm{mmHg}$, tekanan darah diastolik $\geq 85 \mathrm{mmHg}$ atau sedang memakai obat anti hipertensi), dan peningkatan glukosa darah puasa (kadar glukosa puasa $\geq 110 \mathrm{mg} / \mathrm{dL}$, atau $\geq$ 6,10 mmol/L.

Pengumpulan data dilakukan menggunakan kuesioner terstruktur dengan metode wawancara, observasi, pemeriksaan fisik, pengukuran antropometri, dan pemeriksaan biomedis. Data pola konsumsi sayur dan buah difokuskan pada total frekuensi dan porsi sayur dan buah. Informasi frekuensi dan porsi asupan sayur dan buah dikumpulkan dengan menghitung jumlah hari konsumsi dalam seminggu dan jumlah porsi rata-rata dalam sehari dikategorikan menjadi cukup, yaitu konsumsi sayur dan atau buah minimal lima porsi per hari selama tujuh hari dalam seminggu; kurang, yaitu apabila konsumsi sayur dan atau buah kurang dari lima porsi per hari selama tujuh hari dalam seminggu. Data makanan tertentu (makanan manis, asin, berlemak, hewani berpengawet, dan penyedap dikategorikan menjadi sering, yaitu konsumsi makanan tersebut satu kali atau lebih setiap hari; tidak sering, yaitu konsumsi makanan tersebut kurang dari satu kali per hari.

Uji statistik yang dilakukan adalah uji univariat untuk mengetahui besaran prevalensi sindrom metabolik serta uji bivariat untuk mengetahui pola konsumsi makanan, meliputi konsumsi makan sayur dan buah dan makanan tertentu, memengaruhi terjadinya sindrom metabolik dengan menggunakan uji kai kuadrat serta uji multivariat menggunakan regresi logistik biner.

\section{Hasil}

Hasil penelitian diperoleh bahwa sebagian besar sampel berjenis kelamin laki-laki, berusia di bawah 40 tahun, tinggal di perkotaan, serta memiliki pekerjaan dengan status bekerja (Tabel 1).

Ditinjau dari pola konsumsi makanan, hasil penelitian menunjukkan bahwa hampir seluruh sampel kurang mengonsumsi sayur dan buah, yaitu kurang dari lima porsi per hari. Terdapat $54,3 \%$ sampel memiliki pola konsumsi makanan berlemak lebih dari satu kali sehari, $47,2 \%$ menggunakan penyedap rasa lebih dari satu kali 
sehari dan sebagian besar sampel $(83,1 \%)$ mengonsumsi mi instan lebih dari satu kali sehari (Gambar 1).

Pada penelitian ini, penetapan diagnosis sindrom metabolik mengacu pada NCEP ATP III dengan modifikasi dari IDF tahun 2005, yaitu berdasarkan kriteria obesitas sentral (lingkar perut), tekanan darah, kadar glukosa darah puasa, kadar trigliserida, dan HDL (Gambar 2).

Pada Gambar 2 terlihat bahwa sebanyak 34,5\% responden tergolong dalam obesitas sentral (lingkar perut) $\geq 80$ centimeter untuk perempuan dan $\geq 90$ centimeter untuk laki-laki). Terdapat $22 \%$ responden dengan tekanan darah $\geq 130 / 85 \mathrm{mmHg}, 37,9 \%$ memiliki kadar glukosa darah puasa $\geq 110 \mathrm{mg} / \mathrm{dL}, 28,1 \%$ dengan kadar trigliserida darah $\geq 150 \mathrm{mg} / \mathrm{dL}$ serta $39,4 \%$ memiliki kadar HDL yang rendah $(<40 \mathrm{mg} / \mathrm{dL}$ bagi laki-laki dan $<50 \mathrm{mg} / \mathrm{dL}$ bagi perempuan). Menurut kriteria tersebut, hasil penelitian menunjukkan bahwa prevalensi sindrom metabolik pada usia produktif sejumlah $23 \%$. Berdasarkan demografi, lebih banyak sampel perempuan yang mengalami sindrom metabolik, yaitu $26,6 \%$, sedangkan laki-laki sebanyak $18,3 \%$ dan selebihnya tidak mengalami sindrom metabolik. Hasil analisis statistik menggunakan uji kai kuadrat diperoleh nilai probabilitas sebesar 0,001 dengan odds ratio $(\mathrm{OR})=1,622$, artinya terdapat hubungan signifikan antara jenis kelamin dengan kejadian sindrom metabolik, perempuan memiliki risiko 1,622 kali mengalami sindrom metabolik dibandingkan dengan laki-laki.

Tabel 1. Data Demografi Sampel

\begin{tabular}{llll}
\hline Variabel & Kategori & \multicolumn{1}{c}{$\mathbf{n}$} & $\%$ \\
\hline \multirow{2}{*}{ Jenis kelamin } & Laki-laki & 1.075 .413 & 57,2 \\
& Perempuan & 803.165 & 42,8 \\
Usia & $18-39$ tahun & 1.033 .112 & 55 \\
& $40-64$ tahun & 845.466 & 45 \\
Tempat tinggal & Pedesaan & 921.424 & 49 \\
& Perkotaan & 957.154 & 51 \\
Status pekerjaan & Bekerja & 1.158 .784 & 61,7 \\
& Tidak bekerja & 719.794 & 38,3 \\
\hline
\end{tabular}

Ket: $\mathrm{n}=1.878 .578$
Ditinjau dari faktor usia, tampak bahwa sampel yang tidak mengalami sindrom metabolik lebih banyak ditemukan pada usia di bawah 40 tahun dibandingkan dengan usia 40 tahun ke atas. Hasil analisis statistik menunjukkan adanya hubungan signifikan (nilai $\mathrm{p}=0,001$ ). Seseorang yang berusia 40 tahun ke atas berisiko mengalami sindrom metabolik sebanyak 1,951 kali dibandingkan dengan usia di bawahnya. Selain itu, hasil penelitian ini juga mendapatkan adanya hubungan yang signifikan antara status pekerjaan dan tempat tinggal dengan kejadian sindrom metabolik. Orang yang bekerja memiliki risiko lebih tinggi dibandingkan dengan yang tidak bekerja $(\mathrm{OR}=0,783)$. Temuan lain yang diungkap dari penelitian ini adalah bahwa seseorang yang tinggal di pedesaan memiliki risiko mengalami sindrom metabolik sebesar 0,704 kali dibandingkan dengan yang di perkotaan (Tabel 2).

Pola konsumsi makanan yang dianalisis secara bivariat dengan sindrom metabolik meliputi konsumsi sayur dan buah, makanan manis, makanan asin, makanan berlemak, lauk hewani berpengawet, makanan yang diolah dengan menambahkan penyedap rasa dan konsumsi mi instan (Tabel 3).

Tabel 3 menunjukkan bahwa terdapat hubungan yang signifikan antara pola konsumsi sayur dan buah, konsumsi makanan manis dan makanan asin dengan kejadian sindrom metabolik. Seseorang yang mengonsumsi sayur dan buah kurang dari lima porsi setiap hari selama satu minggu memiliki risiko 1,388 kali untuk mengalami sindrom metabolik dibandingkan dengan yang mengonsumsi cukup sayur dan buah. Konsumsi makanan manis lebih dari satu kali per hari memiliki proporsi kejadian sindrom metabolik lebih banyak $(43,5 \%)$ dibandingkan dengan yang kurang dari satu kali per hari $(10,5 \%)$, dengan peluang mengalami sindrom metabolik sebesar 6,567 kali. Adapun seseorang dengan pola konsumsi makanan asin yang termasuk dalam kategori sering memiliki proporsi sindrom metabolik sebesar 100\%, dengan risiko mengalami sindrom metabolik sebanyak 6,363 kali dibandingkan dengan orang yang jarang me-

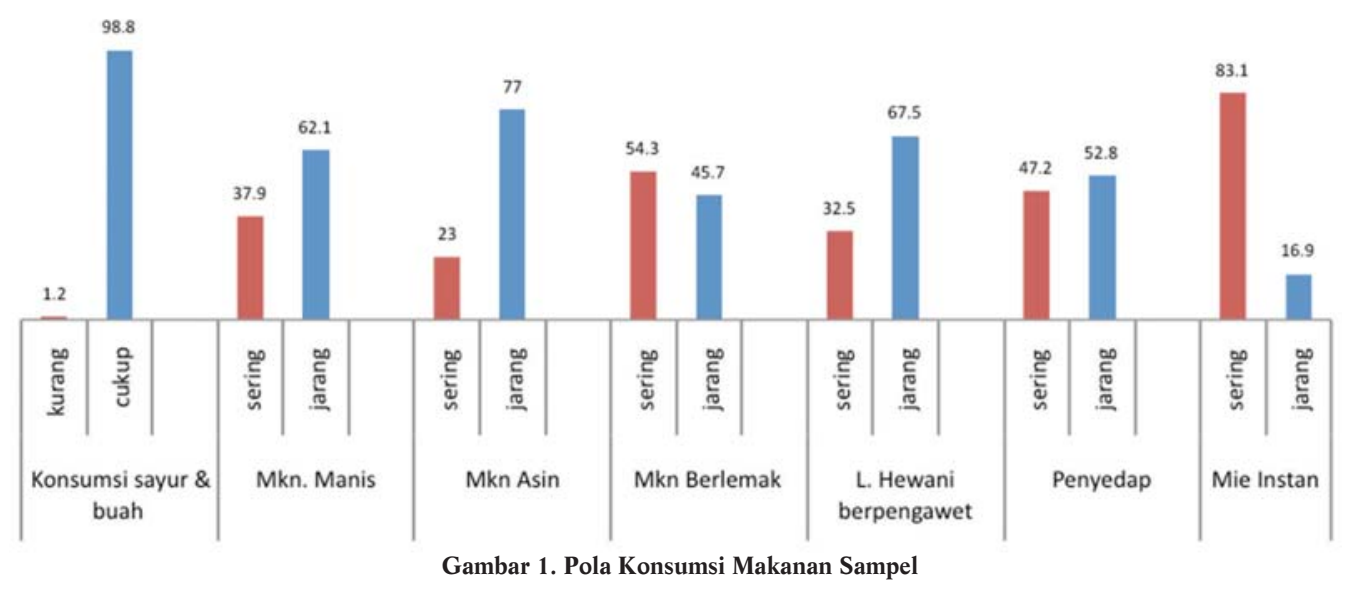


ngonsumsi makanan asin. Adapun konsumsi makanan berlemak, hewani berpengawet, penggunaan penyedap, dan konsumsi mi instan lebih dari satu kali per hari memberikan proporsi kejadian sindrom metabolik yang tidak berbeda jauh dengan yang kurang dari satu kali per hari, dengan OR rata-rata mendekati satu (kisaran 0,899 0,943). Untuk mengetahui faktor-faktor yang berhubungan dengan kejadian sindrom metabolik serta melihat besaran pengaruhnya, maka dilakukan analisis multivariat dengan uji regresi logistik biner yang hasilnya disajikan pada Tabel 4.

Berdasarkan hasil analisis statistik bivariat (Tabel 1,

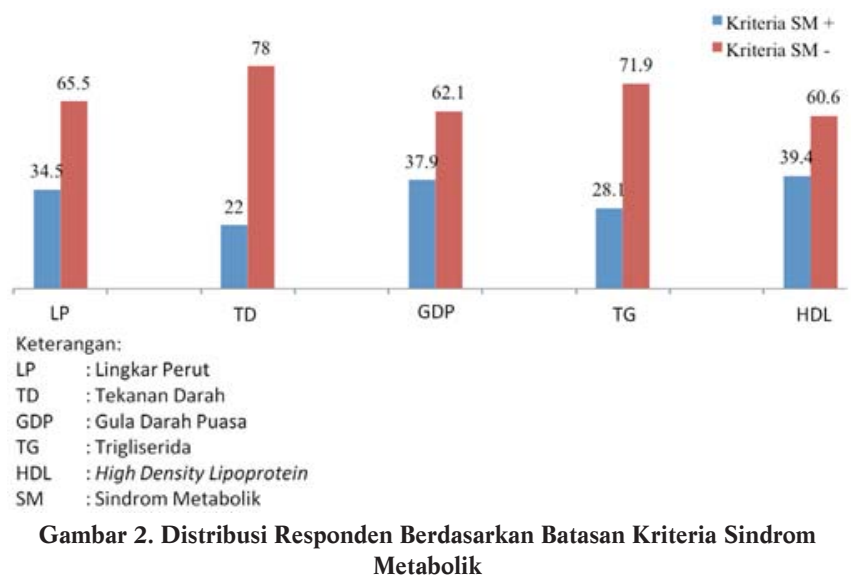

Tabel 2, dan Tabel 3) tampak bahwa secara terpisah semua variabel yang diteliti memiliki hubungan yang signifikan dengan kejadian sindrom metabolik. Namun, hasil analisis multivariat dengan menggunakan regresi logistik biner menunjukkan bahwa hanya konsumsi makanan asin yang secara signifikan merupakan prediktor kejadian sindrom metabolik dengan OR sebesar 1,799 .

\section{Pembahasan}

Hasil penelitian ini menunjukkan bahwa semua variabel bebas yang diteliti memengaruhi kejadian sindrom metabolik secara terpisah. Sindrom metabolik lebih banyak dialami oleh perempuan disebabkan akumulasi lemak tubuh (trigliserida pada jaringan adipose) sehingga menyebabkan hipertrigliseridemia. ${ }^{19}$ Penelitian ini sejalan dengan penelitian Utami dkk, 20 yang mendapatkan sindrom metabolik lebih banyak $(93,94 \%)$ dialami oleh perempuan. Hubungan antara jenis kelamin dan kejadian obesitas sentral diduga karena perbedaan genetik, faktor diet, kurangnya aktivitas fisik berat antara laki-laki dan perempuan. ${ }^{21}$ Selain itu, pada perempuan menopause terjadi penurunan massa otot dan perubahan status hormon. ${ }^{21}$ Adanya akumulasi lemak tubuh yang banyak tersebut (obesitas) berdampak terhadap kejadian resistensi insulin, yang merupakan predisposisi dari keja-

Tabel 2. Hubungan Data Demografi dengan Kejadian Sindrom Metabolik

\begin{tabular}{|c|c|c|c|c|c|c|c|}
\hline \multirow{2}{*}{ Variabel } & \multirow{2}{*}{ Kategori } & \multicolumn{2}{|c|}{ Tidak Sindrom Metabolik } & \multicolumn{2}{|c|}{ Sindrom Metabolik } & \multirow{2}{*}{ Nilai p } & \multirow{2}{*}{ OR } \\
\hline & & $\mathbf{n}$ & $\%$ & $\mathbf{n}$ & $\%$ & & \\
\hline \multirow[t]{2}{*}{ Jenis kelamin } & Perempuan & 789.433 & $73,4 \%$ & 285.980 & $26,6 \%$ & 0,001 & 1,622 \\
\hline & Laki-laki & 656.561 & $81,7 \%$ & 146.604 & $18,3 \%$ & & \\
\hline \multirow[t]{2}{*}{ Usia } & $40-64$ tahun & 595.643 & $70,5 \%$ & 249.822 & $29,5 \%$ & 0,001 & 1,951 \\
\hline & $18-39$ tahun & 850.351 & $82,3 \%$ & 182.762 & $17,7 \%$ & & \\
\hline \multirow[t]{2}{*}{ Status pekerjaan } & Bekerja & 911.469 & $78,7 \%$ & 247.315 & $21,3 \%$ & 0,001 & 0,783 \\
\hline & Tidak bekerja & 534.525 & $74,3 \%$ & 185.269 & $25,7 \%$ & & \\
\hline \multirow[t]{2}{*}{ Tempat tinggal } & Pedesaan & 738.283 & $80,1 \%$ & 183.141 & $19,9 \%$ & 0,001 & 0,704 \\
\hline & Perkotaan & 707.711 & $73,9 \%$ & 249.442 & $26,1 \%$ & & \\
\hline
\end{tabular}

Tabel 3. Hubungan Pola Konsumsi Kejadian Sindrom Metabolik

\begin{tabular}{|c|c|c|c|c|c|c|c|}
\hline \multirow{2}{*}{ Variabel } & \multirow{2}{*}{ Kategori } & \multicolumn{2}{|c|}{ Tidak Sindrom Metabolik } & \multicolumn{2}{|c|}{ Sindrom Metabolik } & \multirow{2}{*}{ Nilai $p$} & \multirow{2}{*}{ OR } \\
\hline & & $\mathbf{n}$ & $\%$ & $\mathbf{n}$ & $\%$ & & \\
\hline \multirow[t]{2}{*}{ Sayur dan buah } & Kurang & 15.554 & $70,7 \%$ & 6.432 & $29,3 \%$ & 0,001 & 1,388 \\
\hline & Cukup & 1.430 .440 & $77,0 \%$ & 426.151 & $23,0 \%$ & & \\
\hline \multirow[t]{2}{*}{ Makanan manis } & Sering & 401.927 & $56,5 \%$ & 309.976 & $43,5 \%$ & 0,001 & 6,567 \\
\hline & Jarang & 1.044 .067 & $89,5 \%$ & 122.607 & $10,5 \%$ & & \\
\hline \multirow[t]{2}{*}{ Makanan asin } & Sering & 68 & $0,00 \%$ & 432.584 & $100 \%$ & 0,001 & 6,567 \\
\hline & Jarang & 1.445 .926 & $100 \%$ & 0 & $0 \%$ & & \\
\hline \multirow[t]{2}{*}{ Makanan berlemak } & Sering & 792.047 & $77,7 \%$ & 227.898 & $22,2 \%$ & 0,001 & 0,919 \\
\hline & Jarang & 653.947 & $76,2 \%$ & 204.686 & $23,8 \%$ & & \\
\hline \multirow[t]{2}{*}{ Makanan hewani berpengawet } & Sering & 477.404 & $78,2 \%$ & 132.848 & $21,8 \%$ & 0,001 & 0,899 \\
\hline & Jarang & 968.590 & $76,4 \%$ & 299.736 & $23,6 \%$ & & \\
\hline \multirow[t]{2}{*}{ Penyedap } & Sering & 686.785 & $77,5 \%$ & 199.086 & $22,5 \%$ & 0,001 & 0,943 \\
\hline & Jarang & 759.209 & $76,5 \%$ & 233.497 & $23,5 \%$ & & \\
\hline \multirow[t]{2}{*}{ Mi instan } & Sering & 1.205 .430 & $77,2 \%$ & 356.182 & $22,8 \%$ & 0,001 & 0,930 \\
\hline & Jarang & 240.564 & $75,9 \%$ & 76.402 & $24,1 \%$ & & \\
\hline
\end{tabular}


Tabel 4. Hasil Uji Regresi Logistik Biner

\begin{tabular}{llll}
\hline Variabel & Nilai p & OR & 95\% CI \\
\hline Jenis kelamin & 0,281 & 2,928 & $0,00-4,68$ \\
Usia & 0,258 & 3,802 & $0,00-2,87$ \\
Tempat tinggal & 0,303 & 2,333 & $0,00-1,90$ \\
Konsumsi makanan manis & 0,402 & 0,000 & $0,00-1,05$ \\
Konsumsi makanan asin & 0,031 & 1,799 & $1,40-2,31$ \\
Konsumsi makanan berlemak & 0,297 & 0,000 & $0,00-0,00$ \\
\hline
\end{tabular}

dian sindrom metabolik. ${ }^{22}$ Obesitas merupakan komponen utama kejadian sindrom metabolik, namun mekanisme yang jelas belum diketahui secara pasti. Obesitas yang diikuti dengan meningkatnya metabolisme lemak akan menyebabkan produksi reactive oxygen species (ROS) meningkat, baik di sirkulasi maupun di sel adiposa. Meningkatnya ROS di dalam sel adiposa dapat menyebabkan keseimbangan reaksi reduksi oksidasi terganggu sehingga enzim antioksidan menurun di dalam sirkulasi. Keadaan ini disebut dengan stres oksidatif. Meningkatnya stres oksidatif menyebabkan disregulasi jaringan adiposa dan merupakan awal patofisiologi terjadinya sindrom metabolik, hipertensi, dan aterosklerosis. ${ }^{23}$ Penelitian lain yang dilakukan di Purwokerto, Jawa Tengah, 30 perempuan yang mengalami sindrom metabolik diketahui memiliki status antioksidan yang rendah (mengalami stres oksidatif). ${ }^{24}$

Faktor usia juga memengaruhi kejadian sindrom metabolik. Semakin bertambah usia, risiko sindrom metabolik semakin meningkat. Pertambahan usia ini berkaitan dengan elastisitas pembuluh darah yang mengalami penurunan, sehingga risiko hipertensi dan terbentuknya endapan aterosklerosis juga bertambah. Semua keadaan tersebut merupakan faktor yang memicu terjadinya sindrom metabolik, sejalan dengan studi potong lintang pada sebagian besar perkotaan di Brazil yang menunjukkan prevalensi sindrom metabolik yang tinggi $(25,4 \%)$, meningkat pada perempuan dengan usia lebih tua dan status sosial ekonomi rendah. Meskipun prevalensi sindrom metabolik hampir sama pada kedua jenis kelamin, tetapi frekuensi komponen yang menentukan sindrom metabolik sangat bervariasi di antara mereka. Secara spesifik, interaksi yang signifikan antara jenis kelamin dan status sosial ekonomi rendah telah ditemukan. Hal tersebut menjelaskan tentang interaksi yang kompleks antara faktor risiko kependudukan dan biologis. Selain faktor tersebut, juga ditemukan bahwa seseorang yang tinggal di pedesaan yang memiliki risiko mengalami sindrom metabolik sebesar 0,704 kali dibandingkan dengan yang di perkotaan. ${ }^{25}$ Penelitian lain di Brazil mengungkap bahwa pendidikan yang tinggi merupakan faktor protektif terhadap kejadian sindrom metabolik. $^{7}$

Sindrom metabolik dapat terjadi akibat kurangnya asupan serat makanan, seperti yang banyak terdapat pada sayur dan buah. Dalam saluran pencernaan, serat larut mengikat asam empedu (produk akhir kolesterol) dan kemudian dikeluarkan bersama tinja. Penelitian pada tikus yang diberikan pakan mengandung $36 \%$ pasta daun gedi merah menurunkan kadar low density lipoprotein (LDL) dan trigliserida secara bermakna. ${ }^{26}$ Selain itu, pada buah terdapat zat bioaktif yang dapat menurunkan kadar kolesterol darah. Hasil penelitian menunjukkan pemberian buah stroberi yang dibekukan kepada orang obesitas dewasa selama 12 minggu berpengaruh pada penurunan kolesterol total dan kecilnya LDL. Penurunan kadar kolesterol pada orang dewasa yang diberikan ini terkait dengan peranan dari antioksidan yang terdapat di dalam buah stroberi. ${ }^{27}$

Konsumsi sayur dan buah yang tidak memadai berkaitan pula dengan rendahnya konsumsi kalium. Keadaan ini memungkinkan seseorang memiliki risiko yang tinggi untuk menderita hipertensi. Di samping itu, konsumsi sayur dan buah dapat mengurangi risiko sindrom metabolik melalui kombinasi dari antioksidan, serat, potasium, magnesium dan photochemical lainnya. Konsumsi sayur dan buah berhubungan dengan penurunan risiko penyakit jantung koroner. Konsumsi sayur dan buah menurunkan risiko penyakit jantung melalui penurunan konsentrasi $C$-reactive Protein (CRP) yang merupakan penanda inflamasi. Penelitian tersebut menunjukkan bahwa konsumsi dari dietary approaches to stop hypertension (DASH) diet, di antaranya diet kaya sayur dan buah, memiliki efek yang menguntungkan pada kejadian sindrom metabolik. ${ }^{13}$ Pemberian buah anggur bubuk selama 30 hari antara lain dapat memperbaiki fungsi endotel, menurunkan tekanan darah sistolik pada laki-laki dewasa yang mengalami sindrom metabolik. ${ }^{28}$

Prevalensi obesitas, baik berdasarkan IMT maupun ukuran lingkar perut, lebih tinggi pada sampel yang sering mengonsumsi makanan manis. ${ }^{12,29,30}$ Kontribusi makanan manis dan berlemak terhadap obesitas memperlihatkan bahwa mekanisme fisiologis mengapa konsumsi makanan manis meningkatkan lemak tubuh melibatkan tingginya densitas energi dan efek rasa lezat makanan manis dan sifat lemahnya kenyang. Hasil penelitian sejalan dengan beberapa penelitian sebelumnya yang menemukan hubungan antara konsumsi makanan berlemak dan peningkatan kejadian obesitas sentral yang merupakan salah satu indikator sindrom metabolik. Kontribusi makanan manis dan berlemak terhadap obesitas memperlihatkan bahwa mekanisme fisiologis yang menjelaskan mengapa konsumsi lemak berperan dalam peningkatan lemak tubuh adalah karena densitas energi yang tinggi, efek rasa lezat makanan berlemak, tingginya efisiensi metabolik, lemahnya kekuatan rasa kenyang, lemahnya regulasi fisiologi asupan 
lemak terhadap asupan karbohidrat. ${ }^{30,31}$

Hasil penelitian ini menunjukkan bahwa konsumsi makanan asin merupakan faktor yang memiliki pengaruh signifikan terhadap kejadian sindrom metabolik. Konsumsi makanan asin dalam jumlah banyak atau dengan frekuensi yang sering akan mengakibatkan asupan natrium juga tinggi. Kandungan natrium setiap porsi ikan asin (20 gram) adalah 579 miligram. ${ }^{32}$ Apabila konsumsi lebih dari satu kali sehari, maka ikan asin memberi kontribusi dua per tiga dari kebutuhan total natrium pengidap hipertensi. Konsumsi natrium yang tinggi akan dapat menyebabkan natrium memasuki sel endotel pembuluh darah arteri. Keberadaan natrium tersebut atrium dapat menarik ion klorida $(\mathrm{Cl})$ dengan kekuatan listrik sehingga terbentuk senyawa $\mathrm{NaCl}$. Senyawa yang baru terbentuk ini akan menarik air dengan kekuatan osmotik sehingga air akan ikut memasuki sel endotel dan sel akan membengkak sehingga mengakibatkan tekanan darah akan naik dan terjadilah hipertensi. ${ }^{33,34}$

\section{Kesimpulan}

Prevalensi sindrom metabolik di Indonesia sebesar $23 \%$, pada perempuan $26,6 \%$ dan pada laki-laki $18,3 \%$. Kejadian sindrom metabolik pada usia produktif di Indonesia berkaitan dengan kebiasaan seringnya mengonsumsi makanan asin, yaitu dengan frekuensi lebih dari satu kali dalam satu hari.

\section{Saran}

Untuk mencegah sindrom metabolik pada kelompok usia produktif, hendaknya memperbaiki pola makan, khususnya mengurangi frekuensi konsumsi makanan asin. Selain itu, membatasi konsumsi makanan manis, makanan berlemak, konsumsi penyedap, dan mi instan tidak lebih dari satu kali per hari serta memperbanyak konsumsi sayur dan buah setidaknya empat sampai dengan lima porsi per hari.

\section{Daftar Pustaka}

1. Kaur J. A comprehensive review on metabolic syndrome. Cardiology Research and Practice. 2014; 2014: ID 943162.

2. Lutsey PL, Steffen LM, Stevens J. Dietary intake and the development of the metabolic syndrome: The atherosclerosis risk in communities study. Circulation [serial on Internet]. 2008; 117(6) :754-61. Available from: http://circ.ahajournals.org/cgi/doi/10.1161/CIRCULATIONAHA.107.716159

3. Alberti KGMM, Zimmet P, Shaw J. Metabolic syndrome-a new worldwide definition. A consensus statement from the International Diabetes Federation. Diabetic Medicine [serial on Internet]. 2006 [cited 2014 Nov 5]; 23 (5): 469-80. Available from: http://doi.wiley.com/ 10.1111/j.1464-5491.2006.01858.x

4. Ford ESG. Prevalence of metabolic syndrome among US adults: findings from the third national health and nutrition examination survey. JAMA. 2002; 287 (3): 356-9.
5. Alberti KGMM, Eckel RH, Grundy SM, Zimmet PZ, Cleeman JI, Donato KA, et al. Harmonizing the metabolic syndrome: a joint interim statement of the International Diabetes Federation task force on epidemiology and prevention; National Heart, Lung, and Blood Institute; American Heart Association; World Heart Federation; International. Circulation [serial on Internet]. 2009 [cited 2014 Dec 5]; 120(16):1640-5. Available from: http://circ.ahajournals.org/cgi /doi/10.1161/CIRCULATIONAHA.109.192644

6. Ervin BR. Prevalence of metabolic syndrome among adults 20 years of age and over, by sex, age, race and ethnicity, and body mass index. National Health and Nutrition Examination Survey. 2009;13 (May 5): 18.

7. Dutra ES, de Carvalho KM, Miyazaki E, Hamann EM, Ito MK. Metabolic syndrome in central Brazil: prevalence and correlates in the adult population. Diabetology and Metabolic Syndrom [serial on Internet]. 2012 [cited 2014 Dec 4]; 4(1): 20. Available from: http://www.pubmedcentral.nih.gov/articlerender.fcgi?artid $=3457864 \&$ tool=pmcentrez $\&$ rendertype $=$ abstract

8. Soewondo P, Purnamasari D, Oemardi M, Waspadji S, Soegondo S. Prevalence of metabolic syndrome using NCEP/ATP III criteria in Jakarta, Indonesia: the Jakarta primary non-communicable disease risk factors surveillance 2006. Acta Medica Indonesia. 2010; 42 (4): 199-203.

9. Kamso S, Purwantyastuti, Lubis DU, Juwita R, Robbi YK, Besral. Prevalensi dan determinan sindrom metabolik pada kelompok eksekutif di Jakarta dan sekitarnya. Kesmas: Jurnal Kesehatan Masyarakat Nasional. 2011; 6 (2): 85-90.

10. Ruidavets J-B, Bongard V, Dallongeville J, Arveiler D, Ducimetiere P, Perret $\mathrm{B}$, et al. High consumptions of grain, fish, dairy products and combinations of these are associated with a low prevalence of metabolic syndrome. Journal of Epidemiology \& Community Health [serial on Internet]. 2007 [cited 2015 Jan 5]; 61(9): 810-7. Available from: http://jech.bmj.com/cgi/doi/10.1136/jech.2006.052126

11. Kementerian Kesehatan Republik Indonesia. Riset kesehatan dasar (Basic Health Research). Jakarta: Kementerian Kesehatan Republik Indonesia; 2013.

12. Esmailzadeh A, Kimiagar M, Mehrabi Y, Azadbakht L, Hu FB, Willett WC. Dietary patterns, insulin resistance and prevalence of the metabolic syndrome in women. American Journal of Clinical Nutrition. 2007; 85(3): $910-8$.

13. Mozaffarian D, Afshin A, Benowitz NL, Bittner V, Daniels SR, Franch HA, et al. Population approaches to improve diet, physical activity, and smoking habits: A scientific statement from the American Heart Association. Circulation [serial on Internet]. 2012 [cited 2015 AJn 5]; 126(12): 1514-63. Available from: http://circ.ahajournals.org/ cgi/doi/10.1161/CIR.0b013e318260a20b

14. Bernard JG, Karen S, Bogani MM SY. The epidemic of cardiovascular disease in the developing world: Global Implication. European Heart Journal. 2010; 31: 642-8.

15. Gaziano TA, Bitton A, Anand S, Abrahams-Gessel S MA. Growing epidemic of corononory heart disease in low-and middle-income countries. Current Problems in Cardiology. 2010; 35 (2) Feb: 75-115.

16. Klein S, Sheard NF, Sunyer XP, Daly A, Rosett JW KK\& CN. Weight management trough life style modification for prevention and manage- 
ment type 2 diabetes. American Journal of Clinical Nutrition. 2004; 80: 257-63.

17. Djaya, Sarimawar, Irianto, Joko, Mulyono L. Pola penyakit penyebab kematian di Indonesia: Survei Kesehatan Rumah Tangga (SKRT) 2001. Majalah Kedokteran Indonesia. 2003; 53(8): 296-302.

18. IDRE: UCLA Institute for Digital Research and Education. Statistical computing seminars introduction to survey data analysis [homepage in Internet]. 2015. Available from: www.ats.ucla.edu.stat/stata/seminars/applied_svy_stataII.

19. Chen H. Enhancing energy and glucose metabolism by distrupting trigliseride syntesis: lesson from Mice Lacking DGAT-1. Nutrition Metabolism [serial on internet]. 2006 [cited 2015 Jan 5];3 (10): about 4 pages. Available from: http://nutritionandmetabolism.biomedcentral.com/articles/10.1186/1743-7075-3-10.

20. Utami, Yunika M, Rosdiana, Dani, Emalia Y. Gambaran asupan gizi pada penderita sindrom metabolik di RW 04 Kelurahan Sidomulyo Kecamatan Tampan Kota Pekan baru. Jurnal Kedokteran Universitas Riau. 2014; 1 (2).

21. Erem C, Arslan C, Hacihasanoglu A, Deger O, Topbas M, Ukinc K, Ersoz HO TM. Prevalence of obesity and associated risk factors in a Turkish Population (Trabzon City, Turkey). Obesity Research. 2004; 12(7): 1117-27.

22. Lee ES, Kim YH, Beck S, Lee S, Oh SW, Sook EON, et al. Social and behavioral depressive mood and abdominal fat distribution in overweight premenopausal women. Obesity Research. 2005; 13(2): 320-5.

23. Furukawa S, Fujita T, Shimabukuro M, Iwaki M, Yamada Y, Nakajima $\mathrm{Y}$, et al. Increased oxidative stress in obesity and its impact on metabolic syndrome. The Journal of Clinical Investigation. 2004; 114: 1752-61.

24. Winarsi H, Wijayanti SPM, Purwanto A. Profil lipid, peroksidasi lipid, dan status inflamatif wanita penderita sindrom metabolik. Kesmas: Jurnal Kesehatan Masyarakat Nasional. 2011; 5 (5): 212-7.

25. Marquezine GF, Olivera CM, Pereira AC, Kriegen JE MJ. Metabolic syndrome determinants in an urban population from Brazil: social class and gender spsesific interaction. International Journal of Cardiology.
129(2):259-65.

26. Gani N, Momuat LI PM. Profil lipid plasma tikus wistar yang hiperkolesterolemia pada pemberian gedi merah (Abelmoschus manihot L. Jurnal MIPA UNSRAT Online. 2013;2(1).

27. Basu A, Betts NM, Nguyen A, Newman ED, Fu D, Lyons TJ. Freezedried strawberries lower serum cholesterol and lipid peroxidation in adults with abdominal adiposity and elevated serum lipids. Journal Nutrition [serial on Internet]. 2014 [cited 2015 jan 5\}; 144(6): 830-7. Available from: http://www.ncbi.nlm.nih.gov/pubmed/24670970

28. Barona J, Aristizabal JC, Blesso CN, Volek JS, Fernandez ML. Grape polyphenols reduce blood pressure and increase flow-mediated vasodilation in men with metabolic syndrome 1. Journal Nutrition. 2012; 142 (9): 1626-32.

29. Miller PE, Perez V. Low-calori sweeteners and body weight n composition: a meta-analysis of randomized control trials and prospective cohort study. American Journal of Clinical Nutrition. 2014; 100 (3): 765-77.

30. Mendoza JA, Drewnowski A, Christakis DA. Dietary energy density is associated with obesity and the metabolic syndrome in US adults. Diabetes Care. 2007; 30 (4): 974-9.

31. Yoo S, Nicklas T, Baranowski T, Zakeri IF, Yang S-J, Srinivasan SR, et al. Comparison of dietary intakes associated with metabolic syndrome risk factors in young adults: the Bogalusa Heart Study. American Journal of Clinical Nutrition. 2004; 80 (4): 841-8.

32. Karmini M. Tabel komposisi pangan Indonesia [internet]. PERSAGI. 2009 [cited 2015 jan 6]. Available from: http://file.persagi.org/ share/79\%20Mien\%20Karmini\%20-\%20DKBM.pdf.

33. Drapeau V, Després JP, Bouchard C, Allard L, Fournier G, Leblanc C, et al. Modifications in food-group consumption are related to long-term body-weight changes. American Journal of Clinical Nutrition. 2004; 80 (1): 29-37.

34. Selmer RM, Kristiansen IS, Haglerod a, Graff-Iversen S, Larsen HK, Meyer HE, et al. Cost and health consequences of reducing the population intake of salt. Journal of Epidemiology and Community Health. 2000; 54 (9): 697-702. 